\title{
Population Structure of Mycosphaerella graminicola: From Lesions to Continents
}

\author{
C. C. Linde, J. Zhan, and B. A. McDonald
}

Institute for Plant Sciences, Phytopathology Group, Federal Institute of Technology, ETH-Zentrum, LFW, Universitätstrasse 2, 8092, Zürich, Switzerland.

Accepted for publication 3 May 2002.

\begin{abstract}
Linde, C. C., Zhan, J., and McDonald, B. A. 2002. Population structure of Mycosphaerella graminicola: From lesions to continents. Phytopathology 92:946-955.

The genetic structure of field populations of Mycosphaerella graminicola was determined across a hierarchy of spatial scales using restriction fragment length polymorphism markers. The hierarchical gene diversity analysis included 1,098 isolates from seven field populations. Spatial scales ranged from millimeters to thousands of kilometers, including comparisons within and among lesions, within and among fields, and within and among regions and continents. At the smallest spatial scale, microtransect sampling was used to determine the spatial distribution of 15 genotypes found among 158 isolates sampled from five individual lesions. Each lesion had two to six different genotypes including both mating types in four of the five lesions, but in most cases a lesion was composed of one or two genotypes that occupied the majority of the

fields for the Swiss, Texas, and Israeli fields was high, ranging from 79 to $100 \%$ of maximum possible values. Low population differentiation was indicated by the low $G_{\mathrm{ST}}$ values among populations, suggesting a corresponding high degree of gene flow among these populations. At the largest spatial scale, populations from Switzerland, Israel, Oregon, and Texas were compared. Population differentiation among these populations was low $\left(G_{\mathrm{ST}}=0.05\right)$, and genetic identity between populations was high. A low but significant correlation between genetic and geographic distance among populations was found $(r=-0.47, P=0.012)$, suggesting that these populations probably have not reached an equilibrium between gene flow and genetic drift. Gene flow on a regional level can be reduced by implementing strategies, such as improved stubble management that minimize the production of ascospores. The possibility of high levels of gene flow on a regional level indicates a significant potential risk for the regional spread of mutant alleles that enable fungicide resistance or the breakdown of resistance genes.
\end{abstract} lesion, with other rare genotypes interspersed among the common genotypes. The majority (77\%) of gene diversity was distributed within plots ranging from $\approx 1$ to $9 \mathrm{~m}^{2}$ in size. Genotype diversity $(G / N)$ within
Additional keywords: gene flow, genetic structure, population genetics, Septoria leaf blotch, Septoria tritici, within lesion diversity.
Neutral genetic markers and hierarchical sampling strategies have enabled plant pathologists to gain a better understanding of the genetic structure of pathogen populations. Knowledge of genetic structure, in turn, has provided insight into the life history of pathogens, including the evolutionary processes that shape pathogen populations in agroecosystems. For example, neutral markers allow us to identify pathogen populations with the greatest genetic diversity that may represent the center of origin for a pathogen. Centers of pathogen diversity are the most promising areas to prospect for resistance genes because these are the locations where coevolution is most likely to have increased the frequency of resistance alleles in natural host populations. Neutral genetic markers also have been used to indicate the potential for gene and genotype flow among populations by measuring the degree of population subdivision among populations across different spatial scales. Measures of population subdivision are available for a number of fungal pathogens, including Magnaporthe grisea (7), Cryphonectria parasitica (32), Sclerotinia sclerotiorum (18), and Rhynchosporium secalis (30). The genetic structure of a pathogen population is likely to affect the pathogen's ability to evolve in response to control measures, such as the deployment of resistant varieties or the application of fungicides (23).

One unexpected result that emerged from the application of neutral genetic markers to plant pathogens was the finding that a

Corresponding author: C. Linde; E-mail address: celeste.linde@ipw.agrl.ethz.ch

Publication no. P-2002-0624-01R

(C) 2002 The American Phytopathological Society lesion is often colonized by several genetically distinct individuals, suggesting that coinfection is relatively common. Examples include Phaeosphaeria nodorum on wheat (27), Alternaria on pear leaves (1), Ascochyta rabiei on chickpea (33), Aspergillus flavus on cotton (2), R. secalis on barley (30), Leptosphaeria maculans on oilseed rape (20), and Mycosphaerella graminicola (Fuckel) J. Schröt. ex Cohn (anamorph Septoria tritici Roberge ex Desmaz.) on wheat $(4,24)$. The distribution of genotypes within lesions provides information regarding the infection event, and it also may provide insight into the relative fitness and competitive abilities of different strains occupying the same lesion. Multiclone infections can arise from infection with a genetically diverse inoculum or from reinfection before an existing infection is fully established. However, it is usually unclear which scenario was followed. In saprophytic fungi such as A. alternata, cocolonization events might result from saprophytic strains taking advantage of preexisting areas of necrotic leaf tissue caused by pathogenic strains (1). A histopathological study of wheat leaves infected with a single isolate of $M$. graminicola indicated that multiple penetrations of a single stomate are possible (15), illustrating how coinfection could occur in M. graminicola. However, we still lack knowledge regarding the spatial arrangement of genotypes within lesions and how competition for space and/or nutrients can affect the spatial arrangement of clones.

M. graminicola is an important wheat leaf pathogen occurring in all major wheat production areas $(11,17)$. M. graminicola is a haploid fungus with a heterothallic mating system. Much information regarding its population biology is already available $(4,9,24$, 25,29 ). Previous studies indicated that the sexual stage has a major impact on the genetic structure of this pathogen $(9,27)$. 
Our objectives were to determine the distribution of genetic diversity in $M$. graminicola populations across a hierarchy of microgeographical and macrogeographical spatial scales. The microgeographical scales included within and among plants sampled from a 1 to $9 \mathrm{~m}^{2}$ area, within and among lesions taken from individual leaves, and among pycnidia taken from single lesions. On the smallest spatial scale, analyses of the distribution of genotypes within lesions could provide information on the potential for competition and genetic interaction among isolates within a lesion. The macrogeographical spatial scales included within and among field populations from different regions and continents, and among sites within a field. Analyses of populations on macrogeographical scales provided us with information regarding population differentiation, gene flow, and genetic diversity of field populations.

\section{MATERIALS AND METHODS}

Fungal isolates. Three field populations collected in 1999 from Switzerland, and two collected in 1994 from Texas, were sampled according to a hierarchical transect method described earlier (30). Populations from Switzerland were sampled from eight locations within three wheat fields. Each field location was approximately $10 \mathrm{~m}$ apart. Ten to thirteen leaves from each field location were sampled and pycnidiospores from one pycnidium per leaf were isolated. In these fields a total area of $8 \mathrm{~m}^{2}\left(8 \times 1 \mathrm{~m}^{2}\right.$ plots $)$ was sampled for each field population. Swiss population 1 (CH1) was collected from cv. Galaxie, population $2(\mathrm{CH} 2)$ from cv. Tamaro, and population $3(\mathrm{CH} 3)$ from cv. Eiger. $\mathrm{CH} 1$ and $\mathrm{CH} 3$ were collected from wheat fields located between Zürich and Winterthur and separated by approximately $20 \mathrm{~km}$. CH2 was collected in southwestern Switzerland, approximately $200 \mathrm{~km}$ from CH1 and $\mathrm{CH} 3$. The Texas populations (TXM and TXP) originated from two fields (cultivars unknown) planted $\approx 10 \mathrm{~km}$ apart near the towns of McKinney and Prosper, respectively, near Dallas. Sampling procedures used for the 1990 Oregon population were described previously (4). This collection was from a replicated cultivar mixture experiment that included 15 treatments. Individual plots measured $\approx 9 \mathrm{~m}^{2}(1.5 \times 6.1 \mathrm{~m})$. A total area of $\approx 342 \mathrm{~m}^{2}$ was sampled in this field. The 1992 Israel population originated from leaves sampled at 1 -m intervals along an $18 \mathrm{~m}$ transect. In total, an area of $\approx 9 \mathrm{~m}^{2}$ was sampled for each of four cvs. Bet Hashita, Ariel, Attir, and Bethlehem. These four cultivars were separated by less than $10 \mathrm{~m}$ in experimental plots located at Nahal Oz. Isolation procedures for the Israel population, and especially those from Bet Hashita and Ariel, differed from other populations as 1 to 8 lesions per leaf were sampled, and more than one isolate was occasionally isolated from the same lesion.

To determine how frequently lesions had more than one genotype, we isolated 2 to 3 pycnidia per lesion in population $\mathrm{CH} 3$ instead of only one pycnidium per lesion as in the non-Israeli populations. In total, 222 isolates from 90 lesions were analyzed. To determine the spatial arrangement of clones within lesions, we used microtransect sampling to collect 40 isolates per lesion from five different wheat plants sampled from the same $1 \mathrm{~m}^{2}$ area in $\mathrm{CH} 3$. Lesions were large enough to permit the isolation of 40 pycnidia per lesion. Pycnidia of $M$. graminicola often occur in rows along stomatal openings, and this allowed us to collect from four parallel transects within each lesion.

DNA extraction and restriction fragment length polymorphism (RFLP) analysis. DNA from the Switzerland M. graminicola populations was extracted with the Qiagen DNA Plant mini extraction kit according to the specification of the manufacturer (Qiagen GmbH, Hilden, Germany). DNA extractions from the other populations were based on cetyltrimethylammoniumbromide (CTAB) as described previously $(4,24)$. Restriction digestion with PstI, Southern blotting, and RFLP analysis were as described previously for $M$. graminicola (4). The seven probes used to ob- tain allele frequencies were $p S T S 192, p S T S 14, p S T L 10, p S T L 53$, pSTS43, pSTL31, and pSTS2. We demonstrated previously that probe $p S T S 192$ hybridizes simultaneously to two loci on different chromosomes $(25,26)$, providing us with eight RFLP loci in total for each isolate. A DNA fingerprinting probe, pSTL70, was used to distinguish clones in all populations except Israel. The fingerprinting probe $p S T L 70$ did not hybridize to enough fragments to differentiate clones in the Israel population. Instead, fingerprinting probe $p S T L 40$ was used to clone-correct data for these isolates in conjunction with the multilocus haplotype information of the single-locus probes. For the intensive analysis of variation within five lesions, only pSTL70 was used. To confirm that putative transposition events in isolates from these lesions were not blotting artifacts, these blots were also hybridized to pSTL40.

Mating type analysis. The mating types of the different genotypes found within the five lesions (microtransect sampling) were determined with a multiplex polymerase chain reaction (PCR) reaction using primers MAT1-1 F, MAT1-1 R, MAT1-2 F, and MAT1-2 R (43). MAT1-1 isolates produce a 340-bp fragment and MAT1-2 isolates produce a 660-bp fragment (43).

Data analysis. Each probe-enzyme combination was treated as a different RFLP locus. DNA fragments or combinations of fragments were treated as different alleles. For probes pSTL70 and pSTL40, the hybridization patterns were used to identify isolates with the same fingerprint. Isolates with the same fingerprint and multilocus haplotype were considered clones. Genotype diversity within local sampling units within each field was measured as the number of unique genotypes divided by the number of isolates in the sample. Comparisons between field populations used the genotype diversity measure of Stoddart and Taylor (41). The significance of differences in genotype diversity for each fieldpopulation was calculated using a $t$ test (8). The gene diversity for each population was calculated using Nei's measure $(H)(35)$. For the $\mathrm{CH} 3$ population, where two to three pycnidia per lesion were isolated, genotypic diversities were corrected for multiple samplings of the same clone by randomly selecting only one isolate per lesion. For allele frequency and gene diversity analysis, multiple isolates from the same lesion were retained after clone correction.

Similarities in the genetic structure of clone-corrected populations were evaluated based on contingency chi-square tests for differences in allele frequencies (46). The Bonferroni correction (44) was applied to all chi-squared tests to reduce Type 1 error. The three field populations from Switzerland, the two from Texas, and Israeli collections from cvs. Bet Hashita and Ariel were tested for differences in allele frequencies. Israel collections from the cvs. Attir and Bethlehem were too small to conduct a meaningful contingency $\chi^{2}$ test. Field populations that tested not significantly different with the $\chi^{2}$ analysis were pooled to represent a larger population from the specific region or country. For the $\chi^{2}$ analysis among Israel, Switzerland, Texas, and Oregon, alleles present at frequencies lower than 0.05 for all four populations were pooled into a single category.

Gene flow was estimated based on the average $G_{\mathrm{ST}}$ (population differentiation) across all eight loci (35), as in previous studies with $M$. graminicola (4). In this method, Nei's $G_{\mathrm{ST}}$ is substituted for $F_{\mathrm{ST}}$ in Wright's island model of gene flow (47). Clone-corrected allele frequency data were used for the analysis of gene diversity, population differentiation, and gene flow. Nei's measure of genetic identity was used to measure genetic similarity between populations (34).

Hierarchical gene diversity analysis (3) was used to partition the distribution of gene diversity across spatial scales, including: (i) within and among continents (United States, Eurasia); (ii) within and among regions within a continent (field populations from Oregon and Texas within the United States); (iii) within and among regions within a country (field populations within Switzer- 
land and Texas); (iv) within and among fields; and (v) within and among field sampling units, including $1 \mathrm{~m}^{2}$ sampling plots for Switzerland and Texas, and $\approx 9 \mathrm{~m}^{2}$ plots for Oregon and Israel field populations. Clone-corrected data were used for these analyses. Because $\chi^{2}$ analysis (46) indicated that the two subpopulations from Texas were significantly different at locus pSTS14, the hierarchical gene diversity analysis (3) was repeated without locus pSTS14, and also with locus pSTS14 included but without the TXM population.

Isolation by distance among all populations was tested using the method described by Slatkin (40). If the amount of gene flow between populations is proportional to physical distance between populations, and the populations are at drift-gene flow equilibrium, the logarithm of the average number of migrants $(\mathrm{Nm})$ per generation between each pair of subpopulations is expected to be negatively correlated with the logarithm of geographic distance between subpopulations.

\section{RESULTS}

Within lesion and within plant diversity. In total, 58 out of 90 lesions $(64 \%)$ were occupied by two or three different genotypes in the $\mathrm{CH} 3$ population. In the Israel Bet Hashita population, 68 isolates originating from 45 lesions were all different genotypes (Table 1). In the lesion microtransect samples, two to six genotypes were identified within each lesion (Figs. 1 and 2). In some lesions, one or two clones occupied the majority of the lesion (genotype 2 in Fig. 2E) whereas, other lesions consisted of several genotypes interspersed among each other (Fig. 2B). Nine of the genotypes identified in the five lesions were MAT1-1 and six were MAT1-2 (Fig. 3). Both mating types occurred in four of the five lesions. Some of the clones exhibited a fingerprint that differed by only one band. These were regarded as a clonal lineage, indicated by a letter following the genotype number (Figs. 2 and 4). These single-band differences could not be detected when the same

TABLE 1. The number of genotypes isolated from leaves, lesions, and subplots within field populations of Mycosphaerella graminicola

\begin{tabular}{|c|c|c|c|c|c|c|c|c|}
\hline Population $^{a}$ & Subpopulation & Cultivar & Area & $\begin{array}{c}\text { Number of } \\
\text { leaves }\end{array}$ & $\begin{array}{l}\text { Number of } \\
\text { lesions }\end{array}$ & $\begin{array}{l}\text { Unique } \\
\text { isolates }\end{array}$ & Total isolates & $\begin{array}{l}\text { Percentage different } \\
\text { genotypes per area }\end{array}$ \\
\hline Switzerland & $\mathrm{CH} 1$ & Total $^{\mathrm{b}}$ & $\begin{array}{l}1 \mathrm{~m}^{2} \\
1 \mathrm{~m}^{2} \\
1 \mathrm{~m}^{2} \\
1 \mathrm{~m}^{2} \\
1 \mathrm{~m}^{2} \\
1 \mathrm{~m}^{2} \\
1 \mathrm{~m}^{2} \\
1 \mathrm{~m}^{2} \\
8 \mathrm{~m}^{2}\left(300 \mathrm{~m}^{2}\right)\end{array}$ & $\begin{array}{r}9 \\
7 \\
6 \\
11 \\
3 \\
5 \\
5 \\
6 \\
52\end{array}$ & $\begin{array}{r}9 \\
7 \\
6 \\
11 \\
3 \\
5 \\
5 \\
6 \\
52\end{array}$ & $\begin{array}{r}9 \\
7 \\
6 \\
9 \\
3 \\
5 \\
5 \\
6 \\
50\end{array}$ & $\begin{array}{r}9 \\
7 \\
6 \\
11 \\
3 \\
5 \\
5 \\
6 \\
52\end{array}$ & $\begin{array}{r}100.0 \\
100.0 \\
100.0 \\
81.8 \\
100.0 \\
100.0 \\
100.0 \\
100.0 \\
96.2\end{array}$ \\
\hline Switzerland & $\mathrm{CH} 2$ & Total $^{\mathrm{b}}$ & $\begin{array}{l}1 \mathrm{~m}^{2} \\
1 \mathrm{~m}^{2} \\
1 \mathrm{~m}^{2} \\
1 \mathrm{~m}^{2} \\
1 \mathrm{~m}^{2} \\
1 \mathrm{~m}^{2} \\
1 \mathrm{~m}^{2} \\
1 \mathrm{~m}^{2} \\
8 \mathrm{~m}^{2}\left(300 \mathrm{~m}^{2}\right)\end{array}$ & $\begin{array}{r}12 \\
8 \\
6 \\
3 \\
7 \\
5 \\
2 \\
5 \\
48\end{array}$ & $\begin{array}{r}12 \\
8 \\
6 \\
3 \\
7 \\
5 \\
2 \\
5 \\
48\end{array}$ & $\begin{array}{r}12 \\
7 \\
6 \\
3 \\
7 \\
5 \\
2 \\
5 \\
47\end{array}$ & $\begin{array}{r}12 \\
8 \\
6 \\
3 \\
7 \\
5 \\
2 \\
5 \\
48\end{array}$ & $\begin{array}{r}100.0 \\
87.5 \\
100.0 \\
100.0 \\
100.0 \\
100.0 \\
100.0 \\
100.0 \\
97.9\end{array}$ \\
\hline Switzerland & $\mathrm{CH} 3$ & Total $^{\mathrm{b}}$ & $\begin{array}{l}1 \mathrm{~m}^{2} \\
1 \mathrm{~m}^{2} \\
1 \mathrm{~m}^{2} \\
1 \mathrm{~m}^{2} \\
1 \mathrm{~m}^{2} \\
1 \mathrm{~m}^{2} \\
1 \mathrm{~m}^{2} \\
1 \mathrm{~m}^{2} \\
8 \mathrm{~m}^{2}\left(300 \mathrm{~m}^{2}\right)\end{array}$ & $\begin{array}{r}12 \\
9 \\
12 \\
13 \\
12 \\
12 \\
10 \\
10 \\
90\end{array}$ & $\begin{array}{r}12 \\
9 \\
12 \\
13 \\
12 \\
12 \\
10 \\
10 \\
90\end{array}$ & $\begin{array}{r}11 \\
9 \\
11 \\
13 \\
11 \\
8 \\
8 \\
9 \\
80\end{array}$ & $\begin{array}{r}12 \\
9 \\
12 \\
13 \\
12 \\
12 \\
10 \\
10 \\
90\end{array}$ & $\begin{array}{r}91.7 \\
100.0 \\
91.7 \\
100.0 \\
91.7 \\
66.7 \\
80.0 \\
90.0 \\
88.9\end{array}$ \\
\hline Switzerland ${ }^{\mathrm{c}}$ & $\mathrm{CH} 3$ & Eiger & $\begin{array}{l}1 \mathrm{~m}^{2} \\
1 \mathrm{~m}^{2} \\
1 \mathrm{~m}^{2} \\
1 \mathrm{~m}^{2} \\
1 \mathrm{~m}^{2} \\
1 \mathrm{~m}^{2} \\
1 \mathrm{~m}^{2} \\
1 \mathrm{~m}^{2} \\
8 \mathrm{~m}^{2}\left(300 \mathrm{~m}^{2}\right)\end{array}$ & $\begin{array}{r}12 \\
9 \\
12 \\
13 \\
12 \\
12 \\
10 \\
10 \\
90\end{array}$ & $\begin{array}{r}12 \\
9 \\
12 \\
13 \\
12 \\
12 \\
10 \\
10 \\
90\end{array}$ & $\begin{array}{r}17 \\
14 \\
19 \\
21 \\
21 \\
9 \\
11 \\
10 \\
122\end{array}$ & $\begin{array}{r}34 \\
23 \\
27 \\
36 \\
30 \\
31 \\
21 \\
18 \\
220\end{array}$ & $\begin{array}{l}50.0 \\
60.9 \\
70.4 \\
58.3 \\
70.0 \\
29.0 \\
52.4 \\
55.6 \\
55.5\end{array}$ \\
\hline Texas & TXM & Unknown & $\begin{array}{l}1 \mathrm{~m}^{2} \\
1 \mathrm{~m}^{2} \\
1 \mathrm{~m}^{2} \\
1 \mathrm{~m}^{2} \\
1 \mathrm{~m}^{2} \\
1 \mathrm{~m}^{2} \\
1 \mathrm{~m}^{2} \\
1 \mathrm{~m}^{2} \\
8 \mathrm{~m}^{2}\left(300 \mathrm{~m}^{2}\right)\end{array}$ & $\begin{array}{r}6 \\
3 \\
5 \\
1 \\
6 \\
2 \\
2 \\
4 \\
29\end{array}$ & $\begin{array}{r}6 \\
3 \\
5 \\
1 \\
6 \\
2 \\
2 \\
4 \\
29\end{array}$ & $\begin{array}{r}5 \\
3 \\
5 \\
1 \\
6 \\
2 \\
3 \\
2 \\
27\end{array}$ & $\begin{array}{r}6 \\
3 \\
5 \\
1 \\
6 \\
2 \\
3 \\
4 \\
30\end{array}$ & $\begin{array}{c}83.3 \\
100.0 \\
100.0 \\
100.0 \\
100.0 \\
100.0 \\
100.0 \\
50.0 \\
90.0\end{array}$ \\
\hline
\end{tabular}

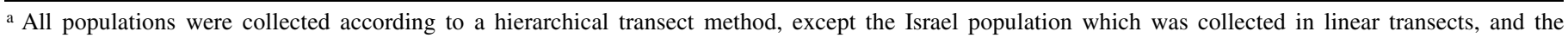
Oregon population which was collected from individual plots.

b The figure in parentheses represents the total field area from which the population originated including unsampled spaces between sampling locations.

c Multiple isolates per lesion and, therefore, not corrected for multiple samples per lesion. 
Southern blots were hybridized to pSTL40 (data not shown). In the Israeli population, isolates from different lesions on the same leaf were always different genotypes (Table 1).

Distribution of diversity within and among fields within a region. In $\mathrm{CH} 1, \mathrm{CH} 2$, and $\mathrm{CH} 3$, the average percentage of unique or novel isolates from a $1 \mathrm{~m}^{2}$ area ranged from 89 to $98 \%$. This decreased to only $56 \%$ when multiple samplings per lesion were considered in $\mathrm{CH} 3$ (Table 1). The average percentage of unique genotypes per $1 \mathrm{~m}^{2}$ area from the TXM and TXP populations was 90 and $100 \%$, respectively (Table 1). No clones were identified in the Israel populations covering an area of $\approx 36 \mathrm{~m}^{2}$ (Table 1 ). In the $9 \mathrm{~m}^{2}$ sampling plots in Oregon, the average percentage of unique genotypes per plot was $91 \%$ (Table 1). The proportion of total gene diversity present among plots within fields across all loci was $17 \%$ and the proportion within plots was $77 \%$ (Table 2). Contingency $\chi^{2}$ tests indicated no significant differences in allele frequencies among all eight loci in the Bet Hashita and Ariel subpopulations, therefore these data sets were pooled to represent Israel. Low population differentiation $\left(G_{\mathrm{ST}}=0.01\right)$ was found between the Bet Hashita and Ariel populations.

Distribution of diversity within and among regions within a continent. Genotypic diversities of field populations were high, e.g., genotypic diversities within the three Swiss fields ranged from 80 to $96 \%$ of the maximum possible values, while no clones were identified in the Israel populations (Table 3 ). The genotype diversities of all field populations within a region did not differ significantly as determined with a $t$ test (Table 3 ). The proportion of total gene diversity present among fields within regions was only $1.2 \%$ (Table 2 ).

Low population differentiation $\left(G_{\mathrm{ST}}=0.01\right)$ was found among the three populations from Switzerland (Table 4). Corresponding estimates of gene flow $(\mathrm{Nm})$ ranged from 58 to 86 (Table 4). Low

TABLE 1. (continued from preceding page)

\begin{tabular}{|c|c|c|c|c|c|c|c|c|}
\hline Population $^{\mathrm{a}}$ & Subpopulation & Cultivar & Area & $\begin{array}{c}\text { Number of } \\
\text { leaves }\end{array}$ & $\begin{array}{c}\text { Number of } \\
\text { lesions }\end{array}$ & $\begin{array}{l}\text { Unique } \\
\text { isolates }\end{array}$ & Total isolates & $\begin{array}{l}\text { Percentage different } \\
\text { genotypes per area }\end{array}$ \\
\hline \multirow[t]{10}{*}{ Texas } & TXP & Unknown & $1 \mathrm{~m}^{2}$ & 7 & 7 & 7 & 7 & 100.0 \\
\hline & & & $1 \mathrm{~m}^{2}$ & 7 & 7 & 7 & 7 & 100.0 \\
\hline & & & $1 \mathrm{~m}^{2}$ & 6 & 6 & 6 & 6 & 100.0 \\
\hline & & & $1 \mathrm{~m}^{2}$ & 7 & 7 & 7 & 7 & 100.0 \\
\hline & & & $1 \mathrm{~m}^{2}$ & 8 & 8 & 8 & 8 & 100.0 \\
\hline & & & $1 \mathrm{~m}^{2}$ & 6 & 6 & 6 & 6 & 100.0 \\
\hline & & & $1 \mathrm{~m}^{2}$ & 2 & 2 & 2 & 2 & 100.0 \\
\hline & & & $1 \mathrm{~m}^{2}$ & 1 & 1 & 1 & 1 & 100.0 \\
\hline & & & $1 \mathrm{~m}^{2}$ & 2 & 2 & 2 & 2 & 100.0 \\
\hline & & Total $^{\mathrm{b}}$ & $9 \mathrm{~m}^{2}\left(350 \mathrm{~m}^{2}\right)$ & 46 & 46 & 46 & 46 & 100.0 \\
\hline \multirow[t]{5}{*}{ Israel } & & Bet Hashita & $9 \mathrm{~m}^{2}$ & 19 & 45 & 68 & 68 & 100.0 \\
\hline & & Ariel & $9 \mathrm{~m}^{2}$ & 19 & 79 & 79 & 79 & 100.0 \\
\hline & & Bethlehem & $9 \mathrm{~m}^{2}$ & 5 & 6 & 6 & 6 & 100.0 \\
\hline & & Attir & $9 \mathrm{~m}^{2}$ & 4 & 5 & 5 & 5 & 100.0 \\
\hline & & Total $^{\mathrm{b}}$ & $36 \mathrm{~m}^{2}\left(540 \mathrm{~m}^{2}\right)$ & 47 & 135 & 158 & 158 & 100.0 \\
\hline \multirow[t]{38}{*}{ Oregon } & & & $9 \mathrm{~m}^{2}$ & 13 & 13 & 8 & 13 & 61.5 \\
\hline & & & $9 \mathrm{~m}^{2}$ & 20 & 20 & 19 & 20 & 95.0 \\
\hline & & & $9 \mathrm{~m}^{2}$ & 19 & 19 & 17 & 19 & 89.5 \\
\hline & & & $9 \mathrm{~m}^{2}$ & 1 & 1 & 1 & 1 & 100.0 \\
\hline & & & $9 \mathrm{~m}^{2}$ & 21 & 21 & 21 & 21 & 100.0 \\
\hline & & & $9 \mathrm{~m}^{2}$ & 15 & 15 & 14 & 15 & 93.3 \\
\hline & & & $9 \mathrm{~m}^{2}$ & 2 & 2 & 2 & 2 & 100.0 \\
\hline & & & $9 \mathrm{~m}^{2}$ & 22 & 22 & 16 & 22 & 72.7 \\
\hline & & & $9 \mathrm{~m}^{2}$ & 11 & 11 & 10 & 11 & 90.9 \\
\hline & & & $9 \mathrm{~m}^{2}$ & 22 & 22 & 22 & 22 & 100.0 \\
\hline & & & $9 \mathrm{~m}^{2}$ & 20 & 20 & 20 & 20 & 100.0 \\
\hline & & & $9 \mathrm{~m}^{2}$ & 13 & 13 & 12 & 13 & 92.3 \\
\hline & & & $9 \mathrm{~m}^{2}$ & 17 & 17 & 15 & 17 & 88.2 \\
\hline & & & $9 \mathrm{~m}^{2}$ & 19 & 19 & 17 & 19 & 89.5 \\
\hline & & & $9 \mathrm{~m}^{2}$ & 17 & 17 & 16 & 17 & 94.1 \\
\hline & & & $9 \mathrm{~m}^{2}$ & 18 & 18 & 17 & 18 & 94.4 \\
\hline & & & $9 \mathrm{~m}^{2}$ & 20 & 20 & 16 & 20 & 80.0 \\
\hline & & & $9 \mathrm{~m}^{2}$ & 5 & 5 & 5 & 5 & 100.0 \\
\hline & & & $9 \mathrm{~m}^{2}$ & 15 & 15 & 14 & 15 & 93.3 \\
\hline & & & $9 \mathrm{~m}^{2}$ & 20 & 20 & 19 & 20 & 95.0 \\
\hline & & & $9 \mathrm{~m}^{2}$ & 19 & 19 & 18 & 19 & 94.7 \\
\hline & & & $9 \mathrm{~m}^{2}$ & 19 & 19 & 17 & 19 & 89.5 \\
\hline & & & $9 \mathrm{~m}^{2}$ & 13 & 13 & 13 & 13 & 100.0 \\
\hline & & & $9 \mathrm{~m}^{2}$ & 13 & 13 & 13 & 13 & 100.0 \\
\hline & & & $9 \mathrm{~m}^{2}$ & 9 & 9 & 9 & 9 & 100.0 \\
\hline & & & $9 \mathrm{~m}^{2}$ & 6 & 6 & 6 & 6 & 100.0 \\
\hline & & & $9 \mathrm{~m}^{2}$ & 8 & 8 & 8 & 8 & 100.0 \\
\hline & & & $9 \mathrm{~m}^{2}$ & 22 & 22 & 19 & 22 & 86.4 \\
\hline & & & $9 \mathrm{~m}^{2}$ & 22 & 22 & 22 & 22 & 100.0 \\
\hline & & & $9 \mathrm{~m}^{2}$ & 22 & 22 & 19 & 22 & 86.4 \\
\hline & & & $9 \mathrm{~m}^{2}$ & 10 & 10 & 10 & 10 & 100.0 \\
\hline & & & $9 \mathrm{~m}^{2}$ & 3 & 3 & 3 & 3 & 100.0 \\
\hline & & & $9 \mathrm{~m}^{2}$ & 11 & 11 & 7 & 11 & 63.6 \\
\hline & & & $9 \mathrm{~m}^{2}$ & 12 & 12 & 9 & 12 & 75.0 \\
\hline & & & $9 \mathrm{~m}^{2}$ & 16 & 16 & 16 & 16 & 100.0 \\
\hline & & & $9 \mathrm{~m}^{2}$ & 17 & 17 & 16 & 17 & 94.1 \\
\hline & & & $9 \mathrm{~m}^{2}$ & 4 & 4 & 4 & 4 & 100.0 \\
\hline & & Total $^{\mathrm{b}}$ & $\approx 342 \mathrm{~m}^{2}\left(\approx 342 \mathrm{~m}^{2}\right)$ & 544 & 544 & 497 & 544 & 91.4 \\
\hline
\end{tabular}


population differentiation was also found between the Texas subpopulations $\left(G_{\mathrm{ST}}=0.01 ; \mathrm{Nm}\right.$ values approached infinity for some loci as a result of division by zero).

Swiss populations $\mathrm{CH} 1$ and $\mathrm{CH} 2$ did not differ in allele frequencies for any RFLP loci. A significant $(P \leq 0.05)$ difference at locus pSTS14 was detected between $\mathrm{CH} 1$ and $\mathrm{CH} 3$ as well as between $\mathrm{CH} 2$ and $\mathrm{CH} 3$. Following the Bonferroni correction, all eight loci in the three Swiss populations were not significantly different. The three Swiss subpopulations were therefore pooled to represent a 'Swiss' population for comparison at the next hierarchical level, within and among continents. Locus pSTS14 also tested significantly different $(P \leq 0.01)$ in the TXM and TXP populations, even after Bonferroni correction. The $\chi^{2}$ value $\left(\chi^{2}=\right.$ 30.576; df $=21$ ) across all eight loci was not significant. In the case of Israel populations, Bet Hashita and Ariel, locus pSTL31 tested significantly different before but not after Bonferroni correction.

Distribution of diversity within and among continents. Frequencies of the most common alleles for all loci across all populations are shown in Table 5. $G_{\mathrm{ST}}$ values across all populations ranged from 0.01 to 0.05 and corresponding $\mathrm{Nm}$ values from 9 to 58 (Table 6). Allele frequencies for all loci across all populations differed significantly $(P=0.001)$ (Table 7$)$. The lowest indicated gene flow was between Oregon and Israel populations, and the highest was between Texas and Oregon (Table 6). Nei's measure of genetic identity between pairs of populations across all loci suggests the same low population differentiation as found with the $G_{\mathrm{ST}}$ analysis (Table 6). Gene diversity for all loci except pSTS192A and pSTS192B was high and similar for all populations

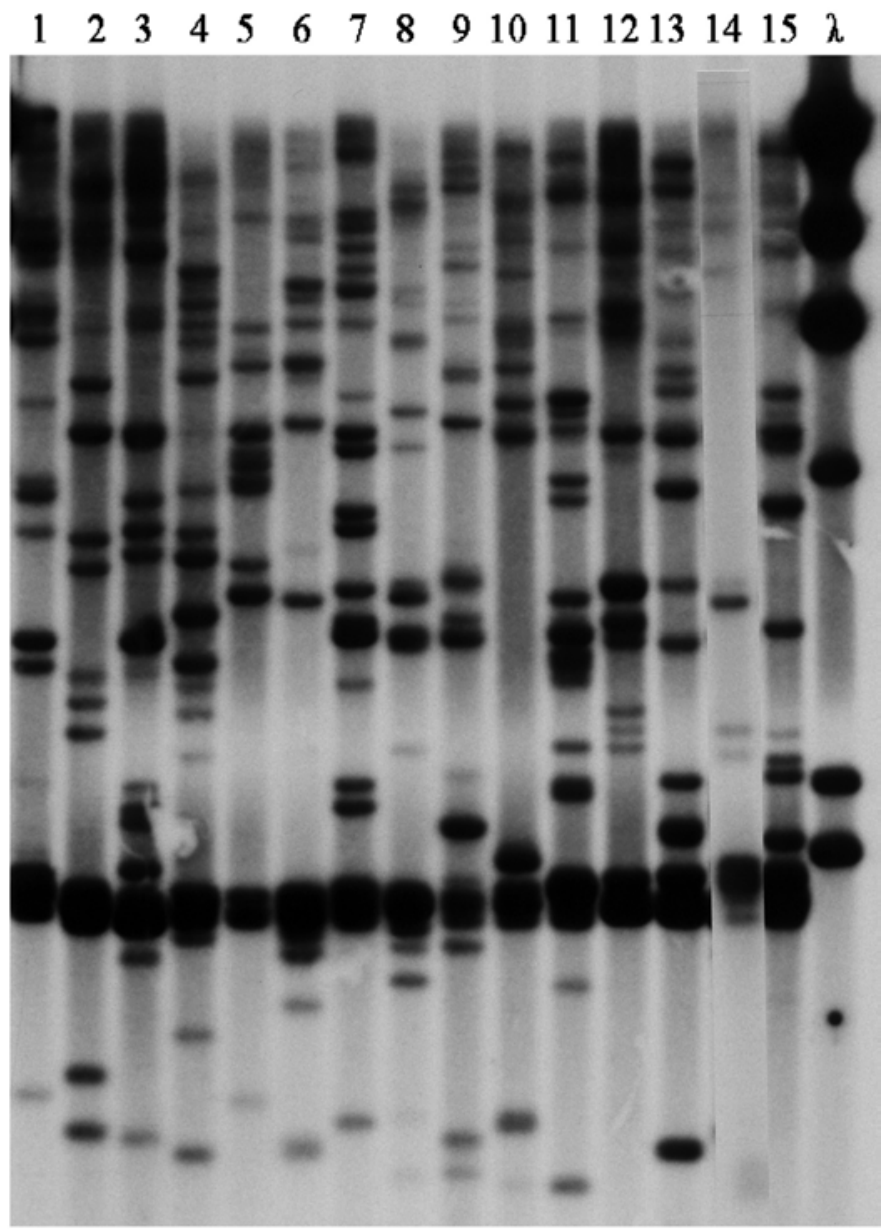

Fig. 1. Restriction fragment length polymorphism (RFLP) fingerprint patterns ( $p S T L 70)$ of the 15 genotypes found within the five lesions analyzed in the microtransect analyses. The last lane is a HindIII size standard.
(Table 7). The highest gene diversities across all loci were obtained for Israel $(H=0.50)$ and Switzerland $(H=0.47)$ (Table 7). A large number of alleles was present in the Swiss, Israel, and Oregon populations (Table 8). Relative to the sample size, the number of alleles was highest in the Israel and Swiss populations (Table 8). The average $G_{\mathrm{ST}}$ across all loci and populations was 0.05 and $\mathrm{Nm}$ was 9 (Table 7).

Hierarchical distribution of total gene diversity. The proportion of total gene diversity present within plots was high at $76.5 \%$. Only $2.5 \%$ of the global diversity was distributed among continents and among regions within continents (Table 2). Performing the analysis without pSTS14, or without TXM (all loci), did not affect the results significantly. Values obtained for among and within continents were identical in all analyses, or differed by a
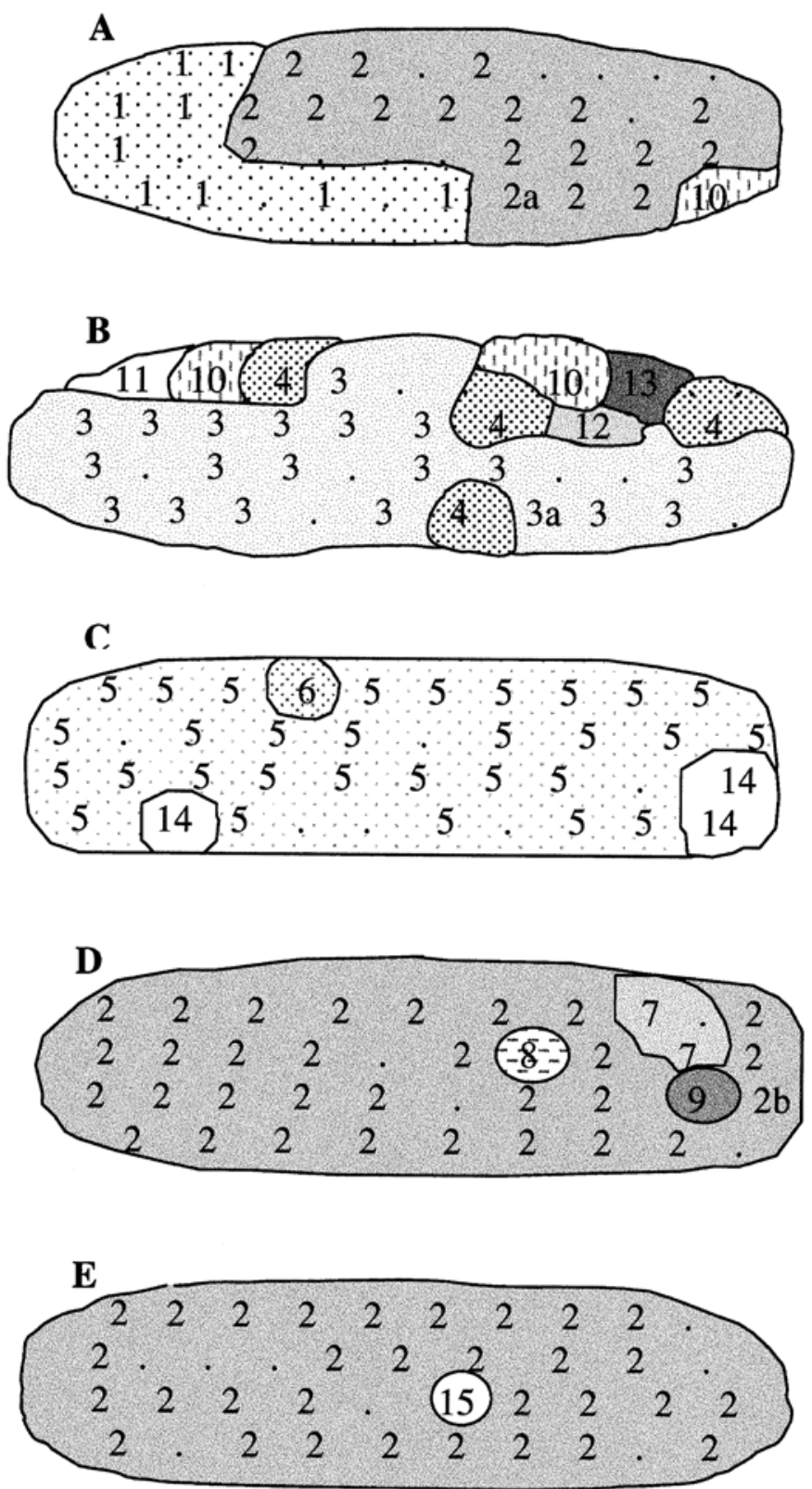

Fig. 2. A schematic diagram of the distribution of Mycosphaerella graminicola genotypes within five naturally infected wheat leaf lesions. Each number indicates a different genotype as determined with a DNA fingerprint probe, $p S T L 70$. Letters following numbers indicate different clonal lineages differing from the most common fingerprint by one fragment. Solid colors indicate MAT1-1 isolates and patterned blocks indicated MAT1-2 isolates. Dots represent positions from which isolations were not successful. 
maximum $0.2 \%$. Comparing the three analyses, values differed by a maximum of $2 \%$ for within field and within plot analyses. Data presented in Table 2 shows the complete analysis including all loci and populations.

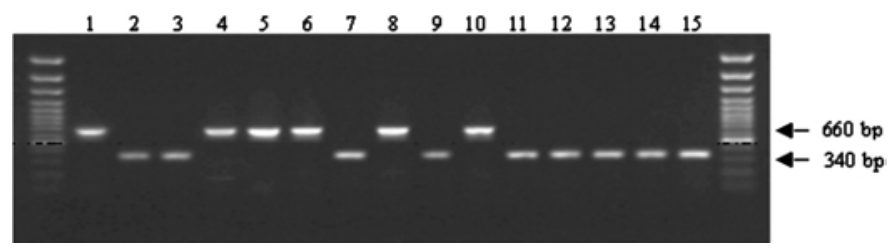

Fig. 3. Multiplex polymerase chain reaction (PCR) with $M A T$ primers of the 15 Mycosphaerella graminicola genotypes found in five naturally infected lesions. First and last lanes are a 100-bp size marker. The numbers on top of the panel indicate the genotype number, which corresponds to the numbers in Figures 1 and 2. The 660-bp amplicon is from MAT1-2 isolates and the 340-bp amplicon from MAT1-1 isolates.
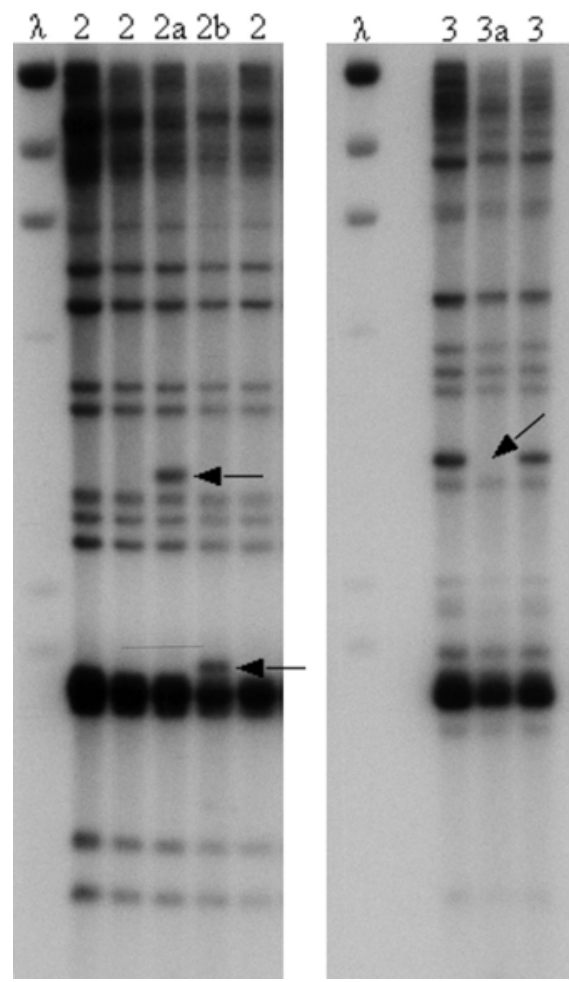

Fig. 4. pSTL70 fingerprint patterns of Mycosphaerella graminicola isolates sampled from the same lesion indicating putative transposition events. The left lane of each panel is a HindIII size marker. Numbers on top of the panels indicate the genotype number, and letters following the number indicate the clonal lineage (shown in Fig. 2) resulting from a putative transposition event. Arrows indicate the bands that appeared or disappeared compared to the most common fingerprint pattern.
If a correlation exists between genetic distance and geographic distance and the populations are at equilibrium, then the logarithm of $\mathrm{Nm}$ should be negatively correlated with the logarithm of the geographic distance between the populations. In our case, the correlation was indeed negative $(r=-0.47 ; P=0.012)$, suggesting isolation by distance, but the correlation was weak (Fig. 5).

\section{DISCUSSION}

We characterized the genetic structure of $M$. graminicola across several spatial scales, and found that populations had high levels of gene and genotypic diversity regardless of the spatial scale analyzed. Single lesions were often occupied by different genotypes, but the number of genotypes per lesion was generally low for most of the lesions analyzed, with two to six genotypes occurring within individual lesions. The highest proportion of the total gene diversity representing populations from two continents was found within sampling units covering an area of 1 to $9 \mathrm{~m}^{2}$. Low levels of population differentiation and corresponding high levels of genetic similarity suggest that gene flow has had a significant impact on the genetic structure of these populations. However, the high gene flow values should be interpreted with caution, as it appears that

TABLE 3. Genotypic diversity in Mycosphaerella graminicola populations

\begin{tabular}{|c|c|c|c|c|c|}
\hline Population & Subpopulation & $\begin{array}{l}\text { Sample } \\
\text { size }\end{array}$ & $\begin{array}{c}\text { Total } \\
\text { number of } \\
\text { leaves }\end{array}$ & $\hat{G}^{\text {a }}$ & $\hat{G} / N(\%)^{\mathrm{b}}$ \\
\hline \multirow[t]{4}{*}{ Switzerland } & $\mathrm{CH} 1$ & 52 & 52 & 48.3 & 92.9 \\
\hline & $\mathrm{CH} 2$ & 48 & 48 & 46.1 & 96.0 \\
\hline & $\mathrm{CH} 3$ & 90 & 90 & 72.4 & 80.4 \\
\hline & Total & 190 & 190 & 165.6 & 87.2 \\
\hline \multirow[t]{3}{*}{ Texas } & TXM & 30 & 29 & 23.7 & 79.0 \\
\hline & TXP & 46 & 46 & 46.0 & 100.0 \\
\hline & Total & 76 & 75 & 71.3 & 93.8 \\
\hline \multirow[t]{5}{*}{ Israel } & Bet Hashita & 68 & 19 & 68.0 & 100.0 \\
\hline & Ariel & 79 & 19 & 79.0 & 100.0 \\
\hline & Attir & 5 & 4 & 5.0 & 100.0 \\
\hline & Bethlehem & 6 & 5 & 6.0 & 100.0 \\
\hline & Total & 158 & 47 & 158.0 & 100.0 \\
\hline Oregon & & 544 & 544 & 449.8 & 82.7 \\
\hline
\end{tabular}

a $\hat{G}=$ genotypic diversity (41).

b $\hat{G} / N(\%)=$ the percentage of maximum possible diversity obtained. Values did not differ significantly at $P=0.05$ as determined with Student's $t$ test (8).

TABLE 4. Pairwise comparisons of population differentiation $\left(G_{\mathrm{ST}}\right)$ (35) (above the diagonal) and gene flow ( $\mathrm{Nm}$ ) (4) (below the diagonal), in field populations of Mycosphaerella graminicola from Switzerland

\begin{tabular}{lccc}
\hline & $\mathrm{CH} 1$ & $\mathrm{CH} 2$ & $\mathrm{CH} 3$ \\
\hline $\mathrm{CH} 1$ & $\ldots$ & 0.009 & 0.007 \\
$\mathrm{CH} 2$ & 53 & $\ldots$ & 0.009 \\
$\mathrm{CH} 3$ & 70 & 58 & $\ldots$ \\
\hline
\end{tabular}

TABLE 2. Hierarchical distribution of genetic variation across spatial scales for all Mycosphaerella graminicola populations analyzed ${ }^{\mathrm{a}}$

\begin{tabular}{|c|c|c|c|c|c|}
\hline \multirow[b]{2}{*}{ Locus } & \multicolumn{5}{|c|}{ Variation } \\
\hline & Among continents & Among regions within continents & Among fields within regions & Among plots within fields & Within plots \\
\hline pSTS192A & 0.013 & 0.015 & 0.005 & 0.084 & 0.882 \\
\hline pSTS192B & 0.079 & 0.043 & 0.002 & 0.221 & 0.656 \\
\hline pSTS14 & 0.009 & 0.019 & 0.039 & 0.234 & 0.700 \\
\hline pSTL10 & 0.006 & 0.027 & 0.011 & 0.150 & 0.806 \\
\hline pSTL53 & 0.012 & 0.015 & 0.014 & 0.165 & 0.795 \\
\hline pSTS43 & 0.037 & 0.026 & 0.005 & 0.185 & 0.747 \\
\hline pSTL31 & 0.013 & 0.029 & 0.021 & 0.165 & 0.772 \\
\hline pSTS2 & 0.029 & 0.023 & 0.001 & 0.189 & 0.759 \\
\hline Average & 0.025 & 0.025 & 0.012 & 0.174 & 0.765 \\
\hline
\end{tabular}

a Total diversity was partitioned into different spatial scale components with a hierarchical gene diversity analysis (3). 
the M. graminicola populations included in this analysis are not at equilibrium according to Slatkin's measure of isolation by distance.

Genetic structure at microgeographical scales-Diversity within and among lesions on a leaf. Diversity among lesions on a leaf was measured only in the Israel population, where isolates from up to six different lesions on the same leaf were all different genotypes. The high within-leaf diversity in Israel may partly reflect the high gene diversity also found in this population, or it may indicate that ascospore infection plays an important role in Israel.

All five lesions intensively sampled in the $\mathrm{CH} 3$ population were composed of more than one genotype. The occurrence of multiple genotypes in a lesion has implications for the life history of this pathogen. Because M. graminicola is a heterothallic fungus, the occurrence of multiple genotypes in the same lesion allows isolates of opposite mating types to come together and reproduce sexually. Frequent sexual reproduction in turn will ensure frequent recombination and increased evolutionary adaptability. The importance of sexual reproduction in the biology of $M$. graminicola was shown previously $(4,9,48)$. It was also shown that field populations in Oregon evolved rapidly (within 3 years) to overcome the resistance in cv. Gene (10), suggesting high selection pressure or that diversity at RFLP loci may reflect diversity for selected loci.

In the structured transects through five lesions, one or two genotypes occupied the majority of each lesion. This finding could reflect the greater fitness or competitive ability of the most common genotype. For example, genotype 2 occupied large areas of three different lesions taken from three leaves. The occurrence of the same genotype in different leaves collected from the same $1 \mathrm{~m}^{2}$ area confirms that short distance dispersal of asexual spores contributes to the epidemic $(24,37)$. We hypothesize that genotype 2 has a higher fitness or competitive ability than the other genotypes detected, though further experiments must be conducted to test this hypothesis.

Coexistence of pathogen clones within the same host plant has manifold biological implications beyond the increased opportunities for sexual reproduction. For example, coexistence can affect host health or infectiousness and affect the transmission success (an important fitness component) of individual clones, thus shaping the evolution of traits such as virulence/aggressiveness or fungi-

TABLE 5. Frequencies of the most common alleles at eight shared restriction fragment length polymorphism (RFLP) loci in the Mycosphaerella graminicola populations collected from Switzerland, Israel, Oregon, and Texas

\begin{tabular}{|c|c|c|c|c|c|}
\hline & & Switzerland & Israel & Oregon & Texas \\
\hline RFLP loci & Allele & $(N=225)$ & $(N=158)$ & $(N=497)$ & $(N=73)$ \\
\hline$p S T S 192 \mathrm{~A}$ & 1 & 0.97 & 0.99 & 0.91 & 1.00 \\
\hline \multirow[t]{2}{*}{ pSTS192B } & 1 & 0.87 & 0.65 & 0.97 & 0.92 \\
\hline & 2 & 0.13 & 0.33 & 0.02 & 0.08 \\
\hline \multirow[t]{2}{*}{ pSTS14 } & 1 & 0.67 & 0.79 & 0.82 & 0.69 \\
\hline & 2 & 0.14 & 0.19 & 0.17 & 0.31 \\
\hline \multirow[t]{2}{*}{ pSTL10 } & 1 & 0.54 & 0.65 & 0.68 & 0.77 \\
\hline & 3 & 0.35 & 0.29 & 0.21 & 0.16 \\
\hline \multirow[t]{5}{*}{ pSTL53 } & 1 & 0.75 & 0.48 & 0.49 & 0.49 \\
\hline & 2 & 0.11 & 0.05 & 0.12 & 0.14 \\
\hline & 3 & 0.04 & 0.34 & 0.14 & 0.18 \\
\hline & 5 & 0.01 & 0.07 & 0.04 & 0.07 \\
\hline & 6 & 0.03 & 0.01 & 0.12 & 0.00 \\
\hline \multirow[t]{3}{*}{ pSTS43 } & 1 & 0.43 & 0.37 & 0.65 & 0.46 \\
\hline & 2 & 0.25 & 0.09 & 0.28 & 0.40 \\
\hline & 3 & 0.07 & 0.27 & 0.05 & 0.13 \\
\hline \multirow[t]{4}{*}{ pSTL31 } & 1 & 0.46 & 0.36 & 0.71 & 0.61 \\
\hline & 2 & 0.13 & 0.04 & 0.15 & 0.20 \\
\hline & 3 & 0.03 & 0.07 & 0.04 & 0.03 \\
\hline & 4 & 0.07 & 0.01 & 0.05 & 0.00 \\
\hline \multirow{3}{*}{$p S T S 2$} & 1 & 0.66 & 0.70 & 0.51 & 0.69 \\
\hline & 2 & 0.00 & 0.01 & 0.40 & 0.20 \\
\hline & 3 & 0.31 & 0.10 & 0.07 & 0.11 \\
\hline
\end{tabular}

cide resistance. For example, competition among genotypes within the same lesion led to reduced sporulation of some genotypes in S. sclerotiorum (21). A competitive advantage within the host will not necessarily translate into higher overall fitness, as shown for coexisting strains of Puccinia graminis $\mathrm{f}$. sp. tritici that differed in sporulation capacity and infection efficiency on wheat leaves (36). Differences in competitive abilities may eventually be exploited for control of plant pathogens such as L. maculans, where coinfection of a weakly virulent strain together with a highly virulent strain induced systemic acquired resistance (20).

Visual inspection of the distribution of genotypes within lesions suggests that interference competition (direct attack or exclusion by mechanical or chemical means) exists in $M$. graminicola. It is especially apparent in lesion A, where the two common genotypes probably represent different infection events separated by a few $\mathrm{mm}$, followed by radial growth leading to a potential overlap in lesions, but no growth into the adjoining, colonized tissue. This pattern suggests interference competition where one individual reduces another individual's access to a limited resource (45). This type of competition might represent the starting point for host or cultivar specificity previously reported for M. graminicola (14, 16). Exploitative competition appears a better explanation for the pattern seen in lesion B, where genotype 4 occurs at various positions within the lesion. Exploitative competition occurs when one individual depletes a limited resource without restricting another individual's access to the resource (19). This may result when genotypes competing for available, uncolonized host tissue grow with intermingled hyphae, and produce pycnidia whenever sufficient nutrients have been sequestered and space is available. Although vegetative incompatibility has not been identified in $M$. graminicola, the possibility that vegetative incompatibility affected these growth patterns cannot be excluded.

The ecology of genetically diverse, naturally acquired infections, has perhaps been most studied in populations of Plasmodium falciparum, the primary causal agent of human malaria and other animal diseases. In this case it has been shown that multiple genotypes in the same lesion (or host individual in this case) can increase competition and thus select for higher aggressiveness/ virulence. Since the fates of the host and the pathogen are tightly linked, extreme host exploitation strategies can ultimately harm the pathogen. Increased pathogen virulence decreases the life expectancy of infected hosts and consequently, the chance of being transmitted to new hosts. There is a trade-off between transmission and within-host exploitation for monoinfections. This trade-off selects for intermediate levels of virulence as observed with animal parasites (22). However, when the host is colonized by multiple pathogen genotypes, this leads to within-host competition and selection for higher pathogen virulence (42). But as mixed-infection pathogen populations evolve to become more virulent, the ability to transmit new infections is expected to decrease, again favoring lower virulence. Thus, an evolutionarily stable strategy to achieve optimum pathogen virulence depends on pathogen interactions within hosts (competition) as well as on pathogen interactions between hosts (transmission) at the popula-

TABLE 6. Pairwise comparisons of population differentiation $\left(G_{\mathrm{ST}}\right)$ (35) (above the diagonal), Nei's measure of gene identity (I) (34) (above the diagonal in parenthesis), and gene flow ( $\mathrm{Nm}$ ) (4) (below the diagonal), in Mycosphaerella graminicola populations from Switzerland, Israel, Oregon, and Texas

\begin{tabular}{lcccc}
\hline & Switzerland & Israel & Texas & Oregon \\
\hline Switzerland & $\ldots$ & 0.03 & 0.02 & 0.03 \\
\multirow{2}{*}{ Israel } & 15 & $(0.91)$ & $(0.92)$ & $(0.95)$ \\
\multirow{2}{*}{ Texas } & 27 & $\ldots$ & 0.03 & 0.05 \\
& & 17 & $(0.92)$ & $(0.89)$ \\
Oregon & 15 & 9 & $\ldots$ & 0.01 \\
& & & 58 & $(0.98)$ \\
\hline
\end{tabular}


tion level. More competitive pathogen genotypes are not necessarily more virulent (42). Further research is needed to determine if selection for higher virulence occurs in plant pathogens such as $M$. graminicola. Our findings suggest that $M$. graminicola offers a useful model to test theories on the evolution of virulence in plant pathogens which show mixed-infections.

A one-band difference in the DNA fingerprints of clonal genotypes obtained from single lesions was observed twice in genotype 2 and once in genotype 3 (Fig. 4). The fingerprinting probe, $p S T L 70$, appears to represent a family of transposable elements that is active in some populations of M. graminicola (12). These single-band differences among clones could be attributable to transposition events (12), or may be artifacts on the autorad due to incomplete digestion, poor hybridization, or contaminated DNA. As replicate DNA preparations from these isolates showed the same pattern, and hybridization with other probes confirmed that the gain or loss of bands was associated only with pSTL70, we believe that the most likely explanation for these observations is actual transposition events. If this explanation is confirmed, it illustrates that transposition occurs at a significant frequency in the Swiss population of M. graminicola.

Genetic diversity within and among plots in a field. Plot sizes within fields covered areas ranging from 1 to $9 \mathrm{~m}^{2}$, and this is where most of the gene diversity was distributed. Combining the gene diversity distributed within and among plots, it meant that almost $94 \%$ of the total gene diversity from the two continents was distributed within individual fields. Total areas sampled within fields ranged from $8 \mathrm{~m}^{2}$ in Texas and Switzerland, to $36 \mathrm{~m}^{2}$ in Israel, and $342 \mathrm{~m}^{2}$ in Oregon. Larger plots and larger fields did not appear to contain greater genotype or greater gene diversity than smaller plots and fields. Rather, the total number of genotypes sampled was mainly a function of the number of lesions sampled within each plot. There was no evidence for population subdivision according to host genotype in the Israeli and Oregon collections where different cultivars were sampled in the same field, or in the Swiss collections from three different cultivars. The similarity in populations sampled from different cultivars offers additional support to our hypothesis that these RFLP loci are selectively neutral (28).

Genetic structure at macrogeographic scales-Genetic diversity among fields within a region. Although the alleles at locus pSTS14 were present at different frequencies in the Texas subpopulations, it affected the hierarchical gene diversity analysis by a maximum of only $2 \%$ and, therefore, the Texas subpopulations were pooled for hierarchical analyses of gene diversity and population differentiation at the regional level. Genetic differentiation among the three field populations in Switzerland and the two field populations in Texas was extremely low as reflected in the low $G_{\mathrm{ST}}$ and corresponding high $\mathrm{Nm}$ values. This indicates that there was no detectable population differentiation within the sampled regions of Switzerland and Texas. We hypothesize that this is due to regional $(10$ to $200 \mathrm{~km})$ gene flow through the movement of airdispersed ascospores among field populations.

Genetic diversity within and among continents. Populations separated by thousands of kilometers and located on different continents were genetically similar as indicated by low population differentiation and high genetic identity. The low levels of population differentiation were reflected in corresponding high values of $\mathrm{Nm}$. Gene flow, indicated by $\mathrm{Nm}$, gives a biological meaning to the mathematical value of population differentiation, indicated by $G_{\mathrm{ST}}$. Although the average gene flow value across all populations $(N m=9)$ was not as high as the values obtained for the three Swiss M. graminicola populations $(\mathrm{Nm}=58$ to 86$)$, it is large enough to suggest that gene flow has occurred between continents. $\mathrm{Nm}=9$ means that an average of 9 individuals would need to be exchanged each generation among Switzerland, Israel, Oregon, and Texas populations to account for their current degree of similarity. Gene flow was highest between the Oregon and Texas $(N m=58)$ populations and significantly higher than previous estimates for M. graminicola populations from Oregon and California (4). This finding was unexpected as the Oregon and California populations were closer than the Oregon and Texas populations. We consider it likely that much of this difference could be related to the fact that only 22 isolates were involved in the calculation of allele frequencies in the original California field population analyzed, and this small sample size may not have been representative of the California population. In addition, many of the RFLP loci used in the previous study were not included in this analysis.

Gene flow among different regions on a continent can be explained by hypothesizing a stepping-stone model where ascospore

TABLE 8. The number of alleles across eight restriction fragment length polymorphism (RFLP) loci in Mycosphaerella graminicola populations from Switzerland, Israel, Oregon, and Texas

\begin{tabular}{|c|c|c|c|c|}
\hline \multirow[b]{3}{*}{ Locus } & \multicolumn{4}{|c|}{ Number of alleles } \\
\hline & Switzerland & Israel & Oregon & Texas \\
\hline & $(N=225)$ & $(N=158)$ & $(N=497)$ & $(N=73)$ \\
\hline$p S T S 192 \mathrm{~A}$ & 5 & 2 & 7 & 1 \\
\hline$p S T S 192 \mathrm{~B}$ & 3 & 4 & 6 & 2 \\
\hline pSTS14 & 7 & 3 & 4 & 2 \\
\hline pSTL10 & 11 & 7 & 17 & 3 \\
\hline pSTL53 & 12 & 7 & 12 & 8 \\
\hline pSTS43 & 10 & 10 & 8 & 4 \\
\hline pSTL31 & 16 & 11 & 10 & 6 \\
\hline pSTS2 & 5 & 9 & 10 & 3 \\
\hline Total & 69 & 53 & 74 & 29 \\
\hline
\end{tabular}

TABLE 7. Gene diversity, population differentiation, gene flow and contingency $\chi^{2}$ tests for differences in allele frequencies for eight restriction fragment length polymorphism (RFLP) loci across four Mycosphaerella graminicola populations

\begin{tabular}{|c|c|c|c|c|c|c|c|c|}
\hline \multirow[b]{2}{*}{ Locus } & \multicolumn{4}{|c|}{ Gene diversity $(H)$} & \multirow[b]{2}{*}{$G_{\mathrm{ST}}^{\mathrm{b}}$} & \multirow[b]{2}{*}{$\mathrm{Nm}^{\mathrm{c}}$} & \multirow[b]{2}{*}{$\chi^{2 \mathrm{~d}}$} & \multirow[b]{2}{*}{$\mathrm{df}^{\mathrm{e}}$} \\
\hline & $\mathrm{CH}^{\mathrm{a}}$ & Israel & Oregon & Texas & & & & \\
\hline$p S T S 192 \mathrm{~A}$ & 0.06 & 0.01 & 0.17 & 0.00 & 0.02 & 25 & $27.9 *$ & 6 \\
\hline$p S T S 192 \mathrm{~B}$ & 0.23 & 0.47 & 0.06 & 0.15 & 0.12 & 4 & $185.4^{*}$ & 6 \\
\hline$p S T S 14$ & 0.51 & 0.33 & 0.29 & 0.42 & 0.02 & 21 & $126.4^{*}$ & 9 \\
\hline$p S T L 10$ & 0.58 & 0.50 & 0.48 & 0.38 & 0.02 & 27 & $49.6^{*}$ & 9 \\
\hline pSTL53 & 0.42 & 0.64 & 0.70 & 0.70 & 0.04 & 12 & $129.8 *$ & 15 \\
\hline pSTS43 & 0.73 & 0.76 & 0.49 & 0.62 & 0.05 & 9 & $282.9 *$ & 18 \\
\hline pSTL31 & 0.75 & 0.74 & 0.47 & 0.58 & 0.06 & 8 & $455.1 *$ & 30 \\
\hline pSTS2 & 0.47 & 0.50 & 0.57 & 0.48 & 0.09 & 5 & $306.5^{*}$ & 15 \\
\hline Average & 0.47 & 0.50 & 0.41 & 0.41 & 0.05 & 9 & & \\
\hline
\end{tabular}

${ }^{a} \mathrm{CH}=$ Switzerland.

b Population differentiation.

c Gene flow.

d * Indicates significance at $P=0.001$.

e Degrees of freedom. 
flights link distant wheat fields over spatial scales of tens to hundreds of kilometers. It is more difficult to explain how gene flow occurs among different continents. We consider it unlikely that ascospores transported in the jet stream are the mechanism for genetic exchange among populations on different continents, though a recent report indicates that dust storms can carry fungal spores between continents (13). It appears more likely that mycelium or pycnidiospores on contaminated seed or grain, as reported by Brokenshire (6), or on infected plant material such as straw (5), offer an effective means for intercontinental dissemination. There is still considerable debate regarding whether $M$. graminicola is seedborne, as it has not yet been shown in vitro (6), however, these large gene flow values provide support for the hypothesis of movement of infected seed, grain, or straw.

An additional uncertainty is related to when gene flow occurred. This study provides some evidence to support the hypothesis of ongoing regional gene flow in $M$. graminicola, because the gene flow values for populations within regions and continents are much higher than values among continents, which are geographically more isolated. The relatively low subdivision (maximum $G_{\mathrm{ST}}=$ 0.05 ) among populations on different continents may be due to moderate levels of contemporary gene flow, but more likely reflects recent colonization (historical gene flow), especially if there has not been enough time for populations to reach an equilibrium between gene flow and genetic drift (38-40). The majority of intercontinental gene flow may have happened hundreds of years ago as a result of import of infected seed and straw into the New World from Europe.

Isolation by distance. Although there was a significant negative correlation between the logarithm of gene flow and geographic distance, the correlation was weak, suggesting moderate isolation by distance in M. graminicola populations. This could be because long distance ascospore migration (hundreds to thousands of $\mathrm{km}$ ) prevents isolation by distance, or because ascospore migration is predominantly short-distance (1 to $10 \mathrm{~km})$ and populations have not yet reached an equilibrium between gene flow and genetic drift. It is however, more likely that the original long-distance gene flow in M. graminicola was man-mediated (i.e., when Europeans introduced wheat into the Americas and Australia), and subsequent natural gene flow gradually reduced the isolation by distance. Unfortunately, we do not have enough data points representing populations separated by short and intermediate distances, otherwise the correlation could be much higher. The only evidence we have for intercontinental dispersal of $M$. graminicola is the high gene flow values, and we cannot determine the temporal scale over which this occurred. The significant differences in allele frequencies among populations on different continents and the moderate isolation by distance, suggests that intercontinental gene flow is less common than transcontinental gene flow. The

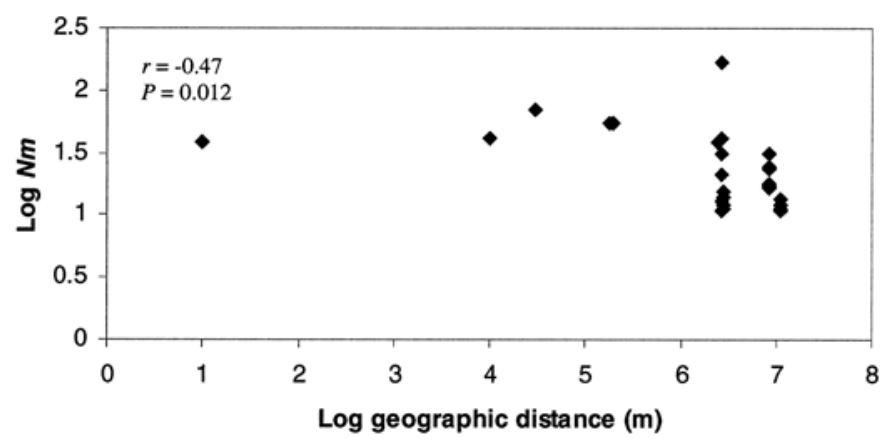

Fig. 5. The relationship between the estimated average number of migrants per generation $(\mathrm{Nm})$ between pairs of Mycosphaerella graminicola subpopulations and geographic distance. $N m$ was estimated using average $G_{\mathrm{ST}}$ (population differentiation) across eight restriction fragment length polymorphism (RFLP) loci (35). There was a weak correlation between $\log \mathrm{Nm}$ and $\log$ (geographic distance) for the 28 population pairs analyzed. gene flow values presented here may overestimate actual gene flow because the effects of gene flow in the past, e.g., colonization events, cannot be distinguished from current gene flow when differentiation among sub-populations is analyzed $(38,39)$.

The average gene diversity across all loci and the number of alleles relative to sample size was highest for the Israel and Switzerland populations. In a previous study comparing eight different populations, the highest gene diversity was clearly in the Israeli population (31). Switzerland was not included in the previous study. The Fertile Crescent is thought to be a center of diversity for M. graminicola and the likely center of origin for the fungus (31). The high gene and genotypic diversity observed over small spatial scales reported here support this hypothesis. The comparably high gene diversity of the Swiss population may be due to the fact that Switzerland is geographically the closest population studied to the Middle East thus far. It also is possible that Switzerland was on an ancient wheat trade route from the Middle East to western Europe and, therefore, inherited much of the genetic diversity from the Middle East by recurring gene flow. This hypothesis can be tested by comparing gene diversity in other populations near the Fertile Crescent. If the Fertile Crescent is the center of origin for $M$. graminicola, and if gene flow has been constant and proportional to distance over time, we expect to find a gradient of gene diversity emanating from the center of origin.

Based on our findings, $M$. graminicola populations have similar genetic structures across a wide geographical area and, therefore, quarantine measures among countries might prove unnecessary to further restrict gene flow. The likelihood that high levels of gene flow occur on a regional scale indicates a substantial risk for the regional spread of mutant alleles that enable the breakdown of resistance genes or fungicide resistance. Since the mutant allele travels regionally in ascospores (gene flow) instead of conidia (genotype flow), the mutant allele will move between fields in a recombined genetic background that has not been preselected for a highly fit combination of coadapted alleles. As a result, the development of new virulent pathotypes or fungicide resistant strains may in many cases be gradual rather than abrupt (23). Gene flow on a regional level could be reduced by strategies that minimize the production of ascospores, such as improved stubble management.

\section{ACKNOWLEDGMENTS}

This work was supported by the USDA National Research Initiative Competitive Grants Program (Grant DEB-9306377), the Swiss National Science Foundation (Grant NF-31-56874.99) and the Swiss Federal Institute of Technology (ETH), Zurich. The authors gratefully acknowledge the assistance of O. Yarden (Hebrew University of Jerusalem), who collected the infected leaves in Israel, C. Mundt and M. Hofer (Oregon State University), who assisted with collections in Oregon, and G. Kema (PRI, Wageningen, The Netherlands) who provided the MAT primer sequences.

\section{LITERATURE CITED}

1. Adachi, Y., and Tsuge, T. 1994. Coinfection by different isolates of Alternaria alternata in single black spot lesions of Japanese pear leaves. Phytopathology 84:447-451.

2. Bayman, P., and Cotty, P. J. 1991. Vegetative compatibility and genetic diversity in the Aspergillus flavus population of a single field. Can. J. Bot. 69:1707-1711.

3. Beckwitt, R., and Chakraborty, R. 1980. Genetic structure of Pileolaria pseudomilitaris (Polychaeta: Spirobidae). Genetics 96:711-726.

4. Boeger, J. M., Chen, R. S., and McDonald, B. A. 1993. Gene flow between geographic populations of Mycosphaerella graminicola (anamorph Septoria tritici) detected with restriction fragment length polymorphism markers. Phytopathology 83:1148-1154.

5. Brokenshire, T. 1975. Wheat debris as an inoculum source for seedling infection by Septoria tritici. Plant Pathol. 24:202-207.

6. Brokenshire, T. 1975. Wheat seed infection by Septoria tritici. Trans. Br. Mycol. Soc. 64:331-335. 
7. Chen, D., Ziegler, R. S., Leung, H., and Nelson, R. J. 1995. Population structure of Pyricularia grisea at two screening sites in the Philippines. Phytopathology 85:1011-1020.

8. Chen, R. S., Boeger, J. M., and McDonald, B. A. 1994. Genetic stability in a population of a plant pathogenic fungus over time. Mol. Ecol. 3:209-218.

9. Chen, R. S., and McDonald, B. A. 1996. Sexual reproduction plays a major role in the genetic structure of populations of the fungus Mycosphaerella graminicola. Genetics 142:1119-1127.

10. Cowger, C., Hoffer, M. E., and Mundt, C. C. 2000. Specific adaptation by Mycosphaerella graminicola to a resistant wheat cultivar. Plant Pathol. 49:445-451.

11. Eyal, Z., Scharen, A. L., Huffman, M. D., and Prescott, J. M. 1985. Global insights into virulence frequencies of Mycosphaerella graminicola. Phytopathology 75:1456-1462.

12. Goodwin, S. B., Cavaletto, J. R., Waalwijk, C., and Kema, G. H. J. 2001. DNA fingerprint probe from Mycosphaerella graminicola identifies an active transposable element. Phytopathology 91:1181-1188.

13. Griffen, D. W., Kellogg, C. A., and Shinn, E. A. 2001. Dust in the wind: Long range transport of dust in the atmosphere and its implications for global public and ecosystem health. Global Change and Human Health 2:20-33.

14. Kema, G. H. J., Annone, J. G., Sayoud, R., Van Silfhout, C. H., Van Ginkel, M., and De Bree, J. 1996. Genetic variation for virulence and resistance in the wheat-Mycosphaerella graminicola pathosystem I. Interactions between pathogen isolates and host cultivars. Phytopathology 86:200-212.

15. Kema, G. H. J., DaZhao, Y., Rijkenberg, F. H. J., Shaw, M. W., and Baayen, R. P. 1996. Histology of the pathogenesis of Mycosphaerella graminicola in wheat. Phytopathology 86:777-786.

16. Kema, G. H. J., Sayoud, R., Annone, J. G., and Van Silfhout, C. H. 1996. Genetic variation for virulence and resistance in the wheat-Mycosphaerella graminicola pathosystem. II. Analysis of interactions between pathogen isolates and host cultivars. Phytopathology 86:213-220.

17. King, J. E., Cook, R. J., and Melville, S. C. 1983. A review of Septoria diseases of wheat and barley. Ann. Appl. Biol. 103:345-373.

18. Kohli, Y., Brunner, L. J., Yoell, H., Milgroom, M. G., Anderson, J. B., Morrall, R. A. A., and Kohn, L. M. 1995. Clonal dispersal and spatial mixing in populations of the plant pathogenic fungus, Sclerotinia sclerotiorum. Mol. Ecol. 4:69-77.

19. Lockwood, J. L. 1992. Exploitation competition. Pages 243-263 in: The Fungal Community: Its Organization and Role in the Ecosystem. G. C. Carrol and D. T. Wicklow, eds. Marcell Dekker, Inc., New York.

20. Mahuku, G. S., Hall, R., and Goodwin, P. H. 1996. Co-infection and induction of systemic acquired resistance by weakly and highly virulent isolates of Leptosphaeria maculans in oilseed rape. Physiol. Mol. Plant Pathol. 49:61-72.

21. Maltby, A. D., and Mihail, J. D. 1997. Competition among Sclerotinia sclerotiorum genotypes within canola stems. Can. J. Bot. 75:462-468.

22. May, R. M., and Anderson, H. M. 1983. Parasite-host coevolution. Pages 186-206 in: Coevolution. D. J. Futuyama and M. Slatkin, eds. Sinauer Associates Inc., Sunderland, MA.

23. McDonald, B. A., and Linde, C. C. 2002. Pathogen population genetics, evolutionary potential, and durable resistance. Annu. Rev. Phytopathol. (In press.)

24. McDonald, B. A., and Martinez, J. P. 1990. DNA restriction fragment length polymorphisms among Mycosphaerella graminicola (anamorph Septoria tritici) isolates collected from a single wheat field. Phytopathology 80:1368-1373.

25. McDonald, B. A., and Martinez, J. P. 1991. DNA fingerprinting of the plant pathogen fungus Mycosphaerella graminicola (anamorph Septoria tritici). Exp. Mycol. 15:146-158.

26. McDonald, B. A., and Martinez, J. P. 1991. Chromosome length poly- morphisms in a Septoria tritici population. Phytopathology 19:265-271.

27. McDonald, B. A., Miles, J., Nelson, L. R., and Pettway, R. E. 1994. Genetic variability in nuclear DNA in field populations of Stagonospora nodorum. Phytopathology 84:250-255.

28. McDonald, B. A., Mundt, C. C., and Chen, R. S. 1996. The role of selection on the genetic structure of pathogen populations: Evidence from field experiments with Mycosphaerella graminicola on wheat. Euphytica 92:73-80.

29. McDonald, B. A., Pettway, R. E., Chen R. S., Boeger, J. M., and Martinez, J. P. 1995. The population genetics of Septoria tritici (teleomorph Mycosphaerella graminicola). Can. J. Bot. 73(suppl.):S292S301.

30. McDonald, B. A., Zhan, J., and Burdon, J. J. 1999. Genetic structure of Rhynchosporium secalis in Australia. Phytopathology 89:639-645.

31. McDonald, B. A., Zhan, J., Yarden, O., Hogan, K., Garton, J., and Pettway, R. E. 1999. The population genetics of Mycosphaerella graminicola and Phaeosphaeria nodorum. Pages. 44-69 in: Septoria on Cereals: A Study of Pathosystems. J. A. Lucas, P. Bowyer and H. M. Anderson, eds. CABI, Wallingford, UK.

32. Milgroom, M. G., and Lipari, S. E. 1995. Population differentiation in the chestnut blight fungus, Cryphonectria parasitica, in eastern North America. Phytopathology 85:155-160.

33. Morjane, H., Geistlinger, J., Harrabi, M., Weising, K., and Kahl, G. 1994. Oligonucleotide fingerprinting detects genetic diversity among Ascochyta rabiei isolates from a single chickpea field in Tunisia. Curr. Genet. 26:191-197.

34. Nei, M. 1972. Genetic distance between populations. Am. Nat. 106:283292.

35. Nei, M. 1973. Analysis of gene diversity in subdivided populations. Proc. Natl. Acad. Sci. USA 70:3321-3323.

36. Newton, M. R., Kinkel, L. L., and Leonard, K. J. 1997. Competition and density-dependent fitness in a plant parasitic fungus. Ecology 78:17741784.

37. Shaw, M. W., and Royle, D. J. 1993. Factors determining the severity of epidemics of Mycosphaerella graminicola (Septoria tritici) on winter wheat in the UK. Plant Pathol. 42:882-899.

38. Slatkin, M. 1985. Gene flow in natural populations. Annu. Rev. Ecol. Syst. 16:393-430.

39. Slatkin, M. 1987. Gene flow and the geographic structure of natural populations. Science 236:787-792.

40. Slatkin, M. 1993. Isolation by distance in equilibrium and nonequilibrium populations. Evolution 47:264-279.

41. Stoddart, J. A., and Taylor, J. F. 1988. Genotype diversity: Estimation and prediction in samples. Genetics 118:705-711.

42. Van Baalen, M., and Maurice, W. S. 1995. The dynamics of multiple infection and the evolution of virulence. Am. Nat. 156:881-910.

43. Waalwijk, C., Mendes, O., Verstappen, E. C. P., de Waard, M. A., and Kema, G. H. J. 2002. Isolation and characterization of the mating-type idiomorphs from the wheat septoria leaf blotch fungus Mycosphaerella graminicola. Fungal Genet. Biol. 35:277-286.

44. Weir, B. S. 1997. Genetic Data Analysis II. Sinauer Associates Inc., Sunderland, MA.

45. Wicklow, D. T. 1992. Interference competition. Pages 265-274 in: The Fungal Community: Its Organization and Role in the Ecosystem. G. C. Carroll and D. T. Wicklow, eds. Marcell Dekker, Inc., New York.

46. Workman, P. L., and Niswander, J. D. 1970. Population studies in Southwestern Indian tribes. II. Local genetic differentiation in the Papago. Am. J. Hum. Genet. 22:24-49.

47. Wright, S. 1951. The genetical structure of populations. Ann. Eugen. 15:323-354.

48. Zhan, J., Mundt, C. C., and McDonald, B. A. 1998. Measuring immigration and sexual reproduction in field populations of Mycosphaerella graminicola. Phytopathology 88:1330-1337. 